\title{
Quantifying river form variations in the Mississippi Basin using remotely sensed imagery
}

\author{
Z. F. Miller, T. M. Pavelsky, and G. H. Allen \\ Department of Geological Sciences, University of North Carolina, Chapel Hill, NC, USA \\ Correspondence to: T. M. Pavelsky (pavelsky@unc.edu)
}

Received: 28 February 2014 - Published in Hydrol. Earth Syst. Sci. Discuss.: 28 March 2014

Revised: 25 September 2014 - Accepted: 8 October 2014 - Published: 5 December 2014

\begin{abstract}
Geographic variations in river form are often estimated using the framework of downstream hydraulic geometry (DHG), which links spatial changes in discharge to channel width, depth, and velocity through power-law models. These empirical relationships are developed from limited in situ data and do not capture the full variability in channel form. Here, we present a data set of $1.2 \times 10^{6}$ river widths in the Mississippi Basin measured from the Landsat-derived National Land Cover Dataset that characterizes width variability observationally. We construct DHG for the Mississippi drainage by linking digital elevation model (DEM)estimated discharge values to each width measurement. Welldeveloped DHG exists over the entire Mississippi Basin, though individual sub-basins vary substantially from existing width-discharge scaling. Comparison of depth predictions from traditional depth-discharge relationships with a new model incorporating width into the DHG framework shows that including width improves depth estimates by, on average, $24 \%$. Results suggest that channel geometry derived from remotely sensed imagery better characterizes variability in river form than do estimates based on DHG.
\end{abstract}

\section{Introduction}

River systems connect the terrestrial and oceanic reservoirs of the hydrologic cycle and play a crucial role in landscape development and freshwater resources. Because spatial changes in river form are physical expressions of interaction between a river's flow and the surrounding environment, they are critical to a wide range of scientific and engineering fields. For example, channel geometry - which includes the key variables of width, depth, velocity, slope, and planform shape - reflects local and regional uplift in bedrock and alluvial rivers and responds to changes in bedrock lithology (Bjerklie, 2007; Whipple, 2004; Montgomery, 2004; Harbor, 1998; Amos and Burbank, 2007; Montgomery and Gran, 2001; Garrett, 1986). River width and depth play a vital role in $\mathrm{CO}_{2}$ and nutrient exchange (Butman and Raymond, 2011; Alexander et al., 2000; Wollheim et al., 2006; Peterson et al., 2001). Aquatic habitat distribution is partially dependent on channel geometry, which both influences the spatial extent of habitats and acts as a barrier to terrestrial species migration (Jowett, 1998; Newson and Newson, 2000; Ayres and Clutton-Brock, 1992; Hayes and Sewlal, 2004). Humans depend on accurate assessments of river form for understanding flooding hazards, transportation planning, and fisheries management (Hobley et al., 2012; Apel et al., 2009; McCartney, 1986; Troitsky, 1994; Prevost et al., 2003). Channel shape is also a principal parameter in hydrologic and hydrodynamic models (Paiva et al., 2013; Neal et al., 2012; Yamazaki et al., 2011). Because of their wide-ranging importance to science and engineering, spatial patterns of channel shape have been studied since at least the work of Leonardo Da Vinci in the 16th century (Humphrey and Abbott, 1867; Bellasis, 1913; Shepherd and Ellis, 1997).

The framework of downstream hydraulic geometry (DHG), developed by Leopold and Maddock (1953), relates spatial patterns of river form to variations in constantfrequency discharge throughout a basin. Three fundamental power-law equations relate width $(w)$, depth $(d)$, and velocity (v) to downstream changes in discharge $(Q)$ :

$w=a Q^{b}$,

$d=c Q^{f}$, 
$v=k Q^{m}$

where $b, f, m, a, c$, and $k$ are exponents and coefficients either derived from physical characteristics or, more commonly, calculated empirically. To facilitate comparison of channel shapes over a large geographic extent, the discharge used in DHG is spatially variable and, ideally, of a constant return period. Some subsequent analyses of natural channels have shown consistency in geometric exponents ( $b \approx 0.5, f \approx 0.4, m \approx 0.1$; Leopold and Maddock, 1953; Leopold and Miller, 1956; Moody and Troutman, 2002; Chaplin, 2005), while others have found variability in exponents related to changes in basin size, tectonic activity, bedrock lithology, channel vegetation, and levels of human influence (Park, 1977; Klein, 1981; Osterkamp and Hedman, 1982; Montgomery and Gran, 2001; Montgomery, 2004; Pietsch and Nanson, 2011).

Most prior investigations of geographic variability in equilibrium channel form rely on in situ measurements of river geometry, which are usually available only at widely spaced locations. This methodology faces two fundamental obstacles in characterizing spatial variations in width and depth. First, the time-intensive nature of in situ channel measurement limits the number of measurement locations to a maximum of hundreds (Moody and Troutman, 2002) to thousands (Lee and Julien, 2006). This restricts either the spatial extent of study areas to smaller basins (e.g., Wolman, 1955) or the density of measurements to wide spacing over larger areas (e.g., Moody and Troutman, 2002; Leopold and Maddock, 1953). Second, in situ channel measurements are often acquired at permanent streamflow gauging sites where accuracy of discharge measurements is usually prioritized, potentially biasing site selection towards desired features such as stable, single-channel cross sections that may not accurately represent the full range of channel characteristics (Rantz, 1982; Ibbitt, 1997). These factors suggest that traditional investigations of river shape may not always encompass the full range of spatial variability in channel geometry. Despite these limitations of DHG in describing geometric variations over regional and continental scales, it is often used to estimate channel characteristics in studies of landscape evolution (Tucker and Bras, 1998); nutrient flux (Carleton and Mohamoud, 2013); carbon emissions (Butman and Raymond, 2011; Raymond et al, 2013); width and depth distributions (Andreadis et al., 2013); and the movement of materials, energy, and organisms (Sabo and Hagen, 2012).

Due to the importance of river form and the difficulty of obtaining wide-scale in situ channel measurements, remote sensing has increasingly been used to characterize river width, depth, and velocity (e.g., Legleiter, 2012; Fonstad and Marcus, 2005; Pavelsky and Smith, 2009; Mersel et al., 2013). As the DHG parameter most readily observable from remotely sensed data, river width has been quantified using a variety of passive and active sensors since the early stages

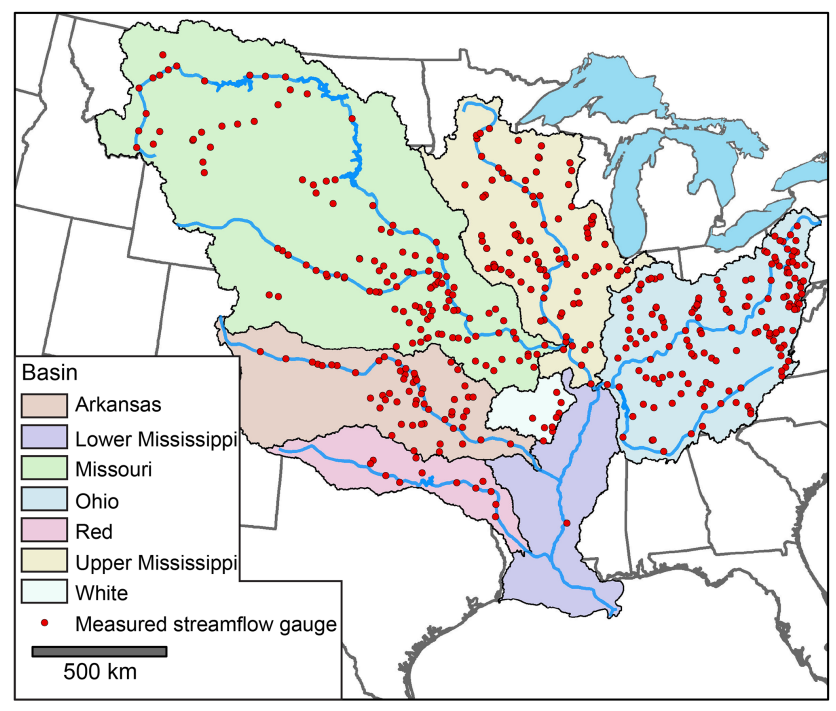

Figure 1. Major sub-basins of the Mississippi and USGS gauging stations used for width validation.

of the Landsat satellite program in the 1970s (Rango and Salomonson, 1974; Watson, 1991; Smith et al., 1996, Allen et al., 2013). While remote sensing of channel width has generally covered single rivers or limited spatial extents, recognition of the potential for large-scale width measurement has recently led to regional and global studies (Pavelsky et al., 2014; Yamazaki et al., 2014; Andreadis et al., 2013).

The RivWidth software tool allows automated and spatially continuous channel width measurements from remotely sensed imagery or other gridded data sources (Pavelsky and Smith, 2008). In this study, we use RivWidth and the Landsat-based National Land Cover Dataset (NLCD) to quantify the spatial variability of river width at approximately mean annual discharge in the Mississippi River Basin and its major sub-basins (Fig. 1). We then match width measurements with mean annual discharge values estimated from discharge-drainage area relationships to construct DHG relationships for the basin as a whole and for major sub-basins. Finally, we use our measured widths and estimated discharge values along with in situ channel width, area, and discharge measurements from U.S. Geological Survey (USGS) streamflow gauging stations to estimate continuous mean channel depths using a multiple linear regression framework. With these high-resolution, spatially extensive data sets we test the large-scale applicability of downstream hydraulic geometry and create a data set that replaces DHG-based estimates for many applications. 

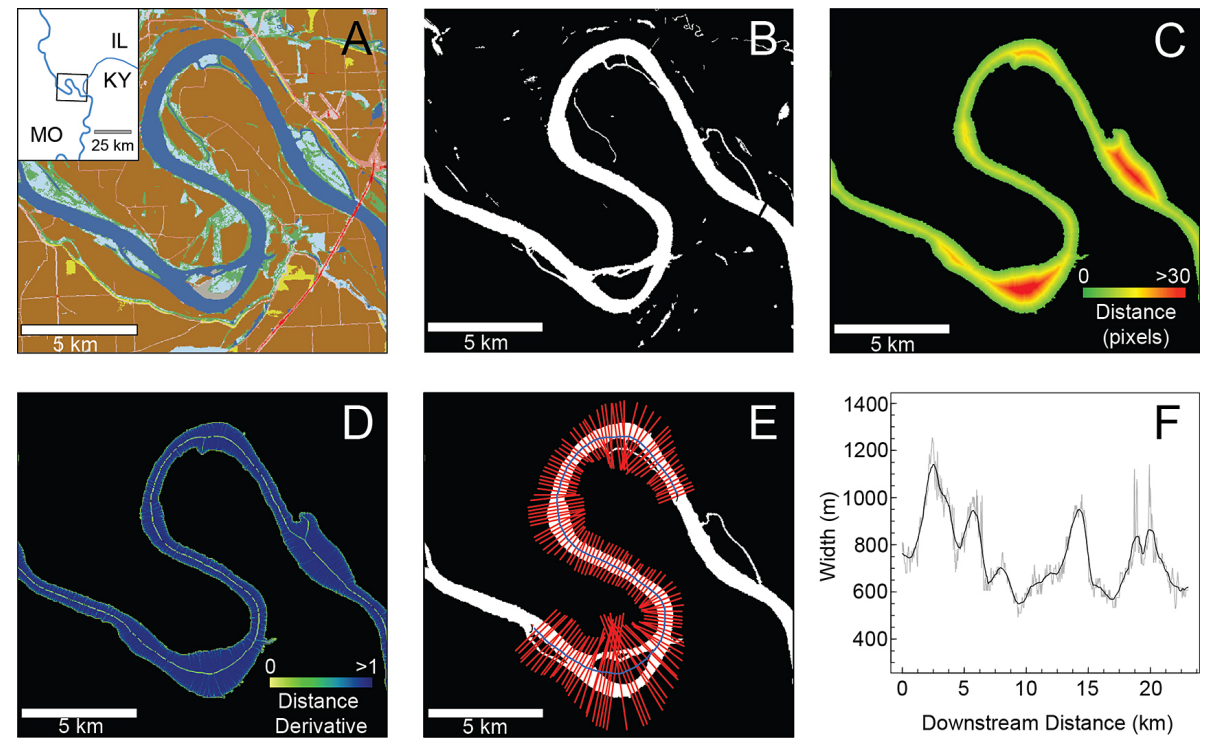

Figure 2. Inputs, intermediate steps, and products for calculation of river width in this study: (a) National Land Cover Dataset; (b) binary water mask of the open-water classification; (c) distance image based on a filled channel mask; (d) derivative of distance image used to calculate the centerline; (e) flow width measurements along orthogonal line segments to each centerline pixel; (f) plot of raw (gray) and smoothed (black) continuous widths.

\section{Data and methods}

\subsection{Calculating river widths}

To develop a high-resolution data set of river widths over a large area, it is necessary to automate width measurement. The RivWidth software tool is designed to calculate river widths from a gridded map of inundation extent (Pavelsky and Smith, 2008). Its functionality allows calculation of river width at each pixel in an automatically derived river centerline, and it can be used on both single-channel and multichannel river reaches. Previous studies have used inputs from MODIS (Moderate-Resolution Imaging Spectroradiometer), Landsat, SPOT-5 (Satellite Pour l'Observation de la Terre) images, and the U.S. Geological Survey's NLCD (Pavelsky and Smith, 2008; Smith and Pavelsky, 2008; Allen et al., 2013; Pavelsky et al., 2014). In this study, we used the open-water class in the NLCD as input to calculate river widths for the Mississippi Basin. The NLCD, derived from $30 \mathrm{~m}$ Landsat imagery, is an integration of land cover extents from early, peak, and late growing seasons (Homer et al., 2004; Wickham et al., 2010). Although inundation extents are not explicitly calibrated to any discharge frequency, we hypothesize that they will, on average, represent mean growing season streamflow. Tests of this hypothesis are described in Sects. 2.2 and 3.2. The NLCD classification was selected for this study because it is a well-established product with thoroughly described methods, and because it covers nearly the entire Mississippi Basin. A small portion of the basin extends outside the coverage of the NLCD into Canada, and this area was not included in our analysis because the tech- niques used to classify open water would be inconsistent with the rest of the basin. To create as complete and continuous a data set as possible, bridges, dams, and other small gaps in river extent were manually removed. Widths were measured at one-pixel intervals (every 30 to $\sim 42 \mathrm{~m}$ ) for all visible continuous channels as narrow as one pixel $(30 \mathrm{~m})$ in width, although not all rivers as narrow as $30 \mathrm{~m}$ were measured (see Sect. 3.1 for details).

To measure river width from remotely sensed imagery, RivWidth (1) creates a channel mask by removing water bodies not connected to the river channel; (2) determines the distance from each river pixel to the nearest non-river pixel and calculates the derivative of the resulting distance image (Fig. 2c and d); (3) determines the river centerline based on the derivative map, in which centerline pixels have values close to 0 and all other river pixels have values of approximately 1; and (4) calculates the flow width along a line segment orthogonal to the direction of flow at each centerline pixel (Fig. 2e). Finally, we eliminated measurements for lakes and reservoirs within the channel systems by removing segments where the NLCD open-water class included clear tributary streams adjoining rivers. Further descriptions, updates, and downloads are available from Pavelsky and Smith (2008) and at http://www.unc.edu/ pavelsky/.

\subsection{Width validation}

To assess the accuracy of RivWidth measurements and the appropriateness of the NLCD for describing channel form at mean flows, we compared in situ USGS channel data corresponding to long-term mean annual discharges to validate 


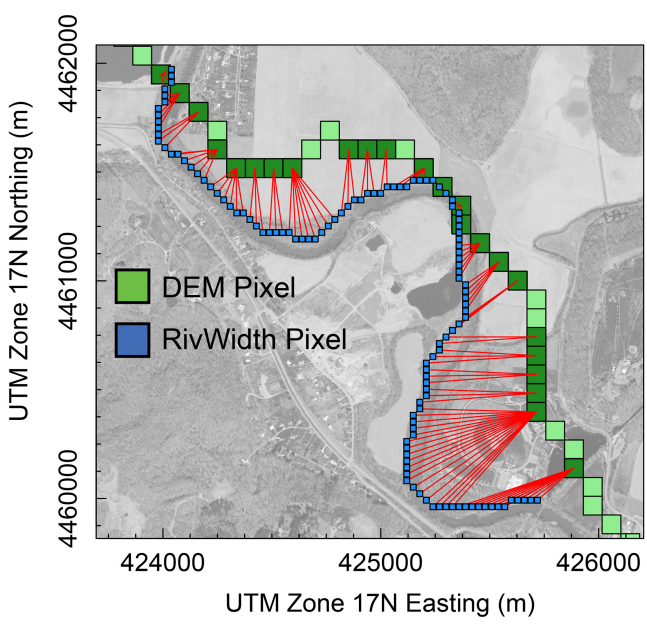

Figure 3. Linking RivWidth and DEM measurements: RivWidth measurements for the Walhonding River near Coshcocton, PA, matched to the nearest downstream DEM-derived channel pixels with drainage area values.

width measurements. Bankfull discharge is often used in fluvial studies because it approximates the dominant channelforming flow (e.g., Wolman, 1955; Leopold and Miller, 1956; Chaplin, 2005; Pietsch and Nanson, 2011). Long-term mean annual discharge is also commonly used to study fluvial processes (Leopold and Maddock, 1953; Griffiths, 1980; Molnar and Ramirez, 2002), and comparison of DHG exponents from a range of flow frequencies shows relatively minor variation (Knighton, 1974; Griffiths, 1980; Ibbitt, 1997). Repeated width, depth, and velocity measurements from the USGS at gauging stations throughout the Mississippi Basin are available online (http://waterdata.usgs.gov/NWIS; Juracek and Fitzpatrick, 2009). Although unpublished, these data have been used in investigations of channel geometry (Bowen and Juracek, 2011; Stover and Montgomery, 2001). The number of measurements at each gauge location varies from fewer than ten to thousands across a range of flows. We removed gauges with fewer than 10 years of mean discharge data and those with no discharge or channel measurements after 1970.

For each gauge, we estimated the width, depth, and velocity corresponding to mean annual discharge by calculating the mean value of all channel measurements acquired within $\pm 10 \%$ of long-term mean annual discharge. Measurements that are clearly erroneous, listed as "poor" by the USGS, taken more than $60 \mathrm{~m}$ (two NLCD pixel lengths) upstream or downstream from the gauge location, or measured using a crane along a bridge not perpendicular to the river (therefore not representing true channel width) were removed. We then calculated total error in our width measurements by comparing in situ gauge width from the 456 stations meeting our criteria against the mean of the five closest RivWidth-derived width measurements.

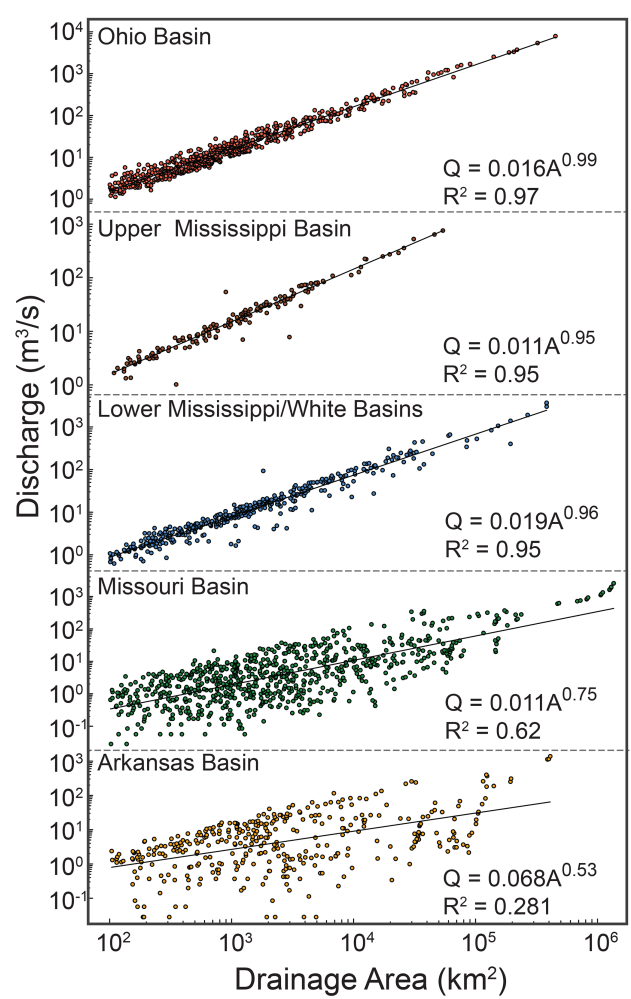

Figure 4. Discharge-drainage area relationships for sub-basins of the Mississippi; exponents close to 1 indicate a nearly linear fit in the Ohio, Upper and Lower Mississippi sub-basins, but there is substantial deviation from unity in the Missouri and Arkansas subbasins.

\subsection{Construction of downstream hydraulic geometry}

Construction of DHG relationships requires knowledge of downstream changes in discharge (Eq. 1a-c) (Leopold and Maddock, 1953). To build DHG relationships continuously downstream, we used upstream drainage area as a proxy for discharge. We calculated drainage area from the $90 \mathrm{~m}$ resolution HydroSHEDS (Hydrological data and maps based on SHuttle Elevation Derivatives at multiple Scales) digital elevation model (DEM) (Lehner et al., 2008) and then assigned the nearest drainage area value to each RivWidth pixel using the methodology developed by Allen et al. (2013) (Fig. 3). A linear relationship between upstream drainage area and discharge has been commonly assumed in small basins (e.g., Pazzaglia et al., 1998; Montgomery and Gran, 2001), but for larger rivers this relationship may become nonlinear if the basin includes variations in geology, tectonic deformation, climate, or land use (Stall and Fok, 1968; Galster et al., 2006; Tague and Grant, 2004). To account for these variations, we developed discharge-drainage area relationships for individual sub-basins using values of discharge and drainage area for all USGS stations with $\geq 10$ years of approved mean annual discharge. Because discharge-drainage area scaling deviates from linearity over large spatial extents 
Table 1. Portions of the Mississippi Basin included in and excluded from the analysis.

\begin{tabular}{|c|c|c|c|c|c|}
\hline & Ohio & Upper Mississippi & Missouri & Arkansas-Red & Lower Mississippi \\
\hline $\begin{array}{l}\text { Accounting } \\
\text { units excluded } \\
\text { from DHG } \\
\text { estimates }\end{array}$ & None & None & $\begin{array}{l}100200,100302, \\
100402,100500, \\
100901,100902, \\
101301,101302, \\
101303,101600, \\
101702,101800, \\
101900,102100, \\
102500,102802\end{array}$ & $\begin{array}{l}\text { All basins other } \\
\text { than } 110100 \\
\text { (Upper White } \\
\text { River excluded) }\end{array}$ & $\begin{array}{l}\text { 080202, 080204, } \\
\text { 080302, 080403, } \\
\text { 080701, 080702, } \\
\text { 080703, 080801, } \\
080802,080901, \\
080902,080903\end{array}$ \\
\hline $\begin{array}{l}\text { Total area } \\
\text { included } \\
\text { (excluded) } \\
\text { in DHG }\end{array}$ & $\begin{array}{l}527900 \mathrm{~km}^{2} \\
\left(0 \mathrm{~km}^{2}\right)\end{array}$ & $\begin{array}{l}429200 \mathrm{~km}^{2} \\
\left(0 \mathrm{~km}^{2}\right)\end{array}$ & $\begin{array}{l}727600 \mathrm{~km}^{2} \\
\left(621700 \mathrm{~km}^{2}\right)\end{array}$ & $\begin{array}{l}57900 \mathrm{~km}^{2} \\
\left(584400 \mathrm{~km}^{2}\right)\end{array}$ & $\begin{array}{l}119600 \mathrm{~km}^{2} \\
\left(129400 \mathrm{~km}^{2}\right)\end{array}$ \\
\hline
\end{tabular}

in some basins (Fig. 4), we calculated least-squares linear regressions for each hydrologic accounting unit (i.e., subbasin) in the Ohio, Upper Mississippi, and much of the Missouri and Lower Mississippi basins. In 7 accounting units containing RivWidth measurements in the Missouri, 12 in the Lower Mississippi, and the entire Arkansas Basin (excluding the White River), lack of gauging stations, substantial precipitation variability, or large-scale water withdrawals precluded gauge-based discharge estimation (Table 1). These sub-basins, along with those not containing rivers large enough to be measured by RivWidth, are not considered in the DHG portion of our analysis.

\subsection{Depth estimation}

We evaluated three methods of calculating spatial depth distributions, each using channel measurements from 358 USGS gauging stations in regions of the Missouri, Upper Mississippi, and Ohio Basins where both RivWidth measurements and DEM-based discharge estimates were available. First, we developed a traditional depth-discharge relationship for the Mississippi using USGS gauge data from within the basin. Second, we estimated depth using the global depth-discharge equation developed by Moody and Troutman (2002). Finally, we performed a multiple linear regression of log-transformed, in situ depth against logtransformed, in situ width and discharge measurements. We then used our measured widths and estimated discharge values to calculate depth at each centerline pixel and evaluated whether including river width as a variable improves depth estimates over depth-discharge methods. We assessed the effectiveness of including the influence of width in depth estimation by calculating the mean percentage error of each depth estimate relative to USGS-measured depth values. Due to increasing uncertainty in RivWidth measurements and discharge estimations for smaller rivers, we limited this depth validation to rivers wider than $100 \mathrm{~m}$.

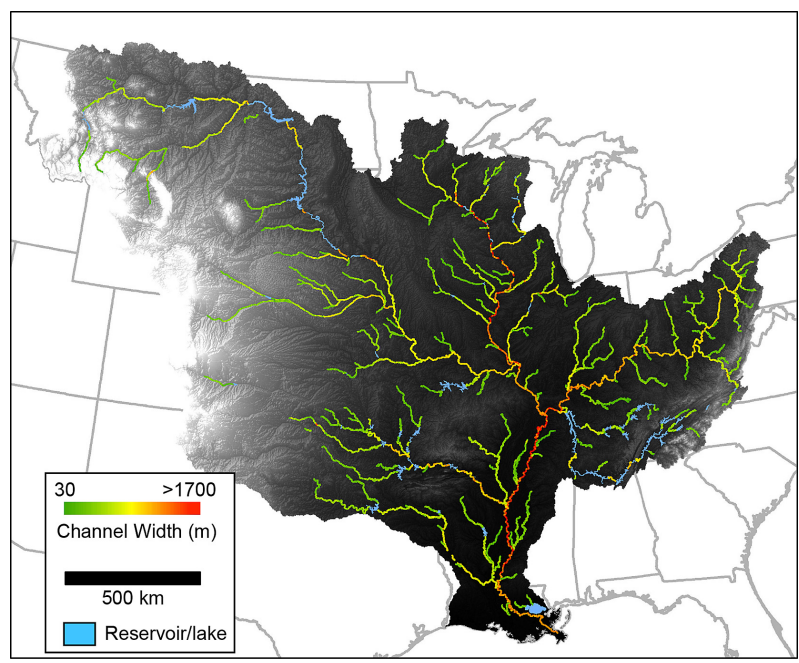

Figure 5. Mississippi River width map (shown with USGS HydroSHEDS DEM) of $\sim 1.2 \times 10^{6}$ observations at $30 \mathrm{~m}$ resolution based on the NLCD open-water classification

\section{Results}

\subsection{Measurement and distribution of river widths}

Using the National Land Cover Dataset, we measured $1.19 \times$ $10^{6}$ individual channel widths representing $42 \times 10^{3} \mathrm{~km}$ of rivers in the Mississippi Basin (Fig. 5). Widths ranged from the minimum pixel size of 30 to $7400 \mathrm{~m}$ in the inundated areas of the Upper Mississippi. Measurement count and length for each of the five sub-regions of the Mississippi are shown in Table 2. Overall distribution of river widths greater than $100 \mathrm{~m}$ and less than $1500 \mathrm{~m}$ (Fig. 6) closely follows a negative power-law distribution:

$n=2.1 \times 10^{9} W^{-1.9}$,

where $n$ is the number of pixels of a corresponding width and $W$ is the width. Bars for rivers $<100 \mathrm{~m}$ in width are in- 
Table 2. Width measurement count and river length.

\begin{tabular}{c|rrrrr|r}
\hline Hydrologic region & Ohio-Tennessee & Upper Mississippi & Lower Mississippi & Arkansas-Red & Missouri & Total \\
\hline$n$ & 304685 & 223259 & 137055 & 218604 & 311029 & 1194632 \\
Length $(\mathrm{km})$ & 10761 & 7872 & 4819 & 7699 & 10944 & 42095 \\
\hline
\end{tabular}

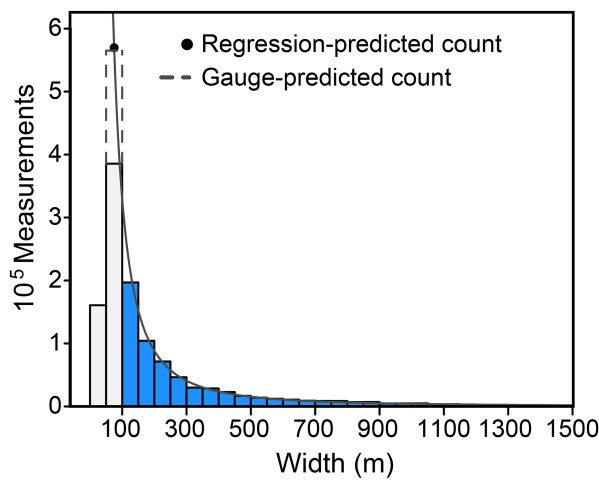

Figure 6. Width distributions for all rivers $>100 \mathrm{~m}$ (blue bars) and all measured rivers $<100 \mathrm{~m}$ (gray bars); black circle represents measurements predicted by the $100-1500 \mathrm{~m}$ distribution regression ( $n=570000$, black line); dashed gray lines show estimated number of 50-100 m rivers from the frequency distribution of USGS river gauges $(n=565000)$.

cluded in Fig. 6 to indicate the distribution of width data analyzed here, but because we do not capture all rivers at these widths our data set cannot be used to describe the true distribution of rivers $<100 \mathrm{~m}$ wide. To evaluate the completeness of this data set and assess its accuracy, we downloaded historical channel measurements from 2466 USGS streamflow gauges taken at long-term mean annual discharge. Of these, widths are greater than $30 \mathrm{~m}$ (the minimum width theoretically measurable) at 854 locations. Figure 7 shows the percentage of gauges measured in $10 \mathrm{~m}$ width increments. Almost all (> $99 \%$ ) gauge locations wider than $90 \mathrm{~m}$ are measured, while the most substantial decrease occurs as width falls below $60 \mathrm{~m}$ (two NLCD pixels).

The two $100 \mathrm{~m}$ gauges not captured by RivWidth are in areas with ambiguous river boundaries, in which the NLCD contains adjacent areas of open water and woody wetlands. At widths between 60 and $100 \mathrm{~m}$, unmeasured stations are more common because not all channels in this size range are adequately captured in the NLCD. The rapid reduction in the percentage of gauges measured at less than $60 \mathrm{~m}$ is likely related to difficulties in classifying mixed land-water pixels, which often represent the entire river as width decreases below twice the pixel resolution.

We use two separate methods to estimate the actual length of rivers between 50 and $100 \mathrm{~m}$ in the Mississippi Basin. First, comparison with USGS gauge data suggests that RivWidth measured $\sim 68 \%$ of gauges $50-100 \mathrm{~m}$ in width. We use this percentage as a correction factor, dividing the

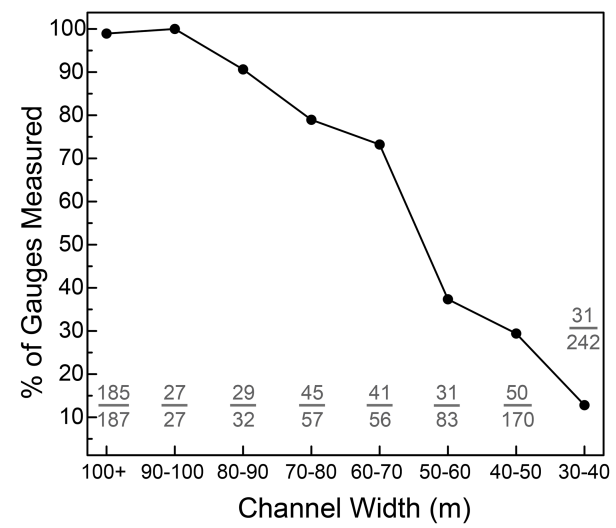

Figure 7. Percentage of USGS gauging stations measured in this study, binned by in situ channel width; gray fractions indicate number measured out of total gauges per $10 \mathrm{~m}$ width range.

number of $50-100 \mathrm{~m}$ river measurements made here by 0.68 to estimate the correct number of measurements (the dashed box in Fig. 6). Second, we use Eq. (2) to extrapolate from the distribution of measurements for rivers wider than $100 \mathrm{~m}$ to those between 50 and $100 \mathrm{~m}$ in width (the dot in Fig. 6). These two methods produce nearly identical values.

\subsection{Width measurement accuracy}

Compared to widths at mean annual discharge from 456 gauging stations in the Ohio-Tennessee, Upper Mississippi, Missouri, and Arkansas regions, mean absolute width error (MAE) is $38 \mathrm{~m}$ (Fig. 8). Many gauges in the Lower Mississippi region are located in low-lying areas where flow is not confined to a single channel, causing the USGS measurements to include areas that the NLCD classifies as woody wetlands or something other than open water. Because of these complications, gauging stations not on the main stem of the Lower Mississippi are excluded. Total mean and median errors of 20 and $11 \mathrm{~m}$ indicate a slight positive bias in RivWidth measurements, although outliers with positive errors of more than $600 \mathrm{~m}$ skew the errors substantially. This error can be partitioned into three groups: water mask error, RivWidth error, and inaccuracies in USGS measurements. While stations with measured $W>60 \mathrm{~m}$ show a median positive bias of only $16 \mathrm{~m}$, stations where $W<60 \mathrm{~m}$ have a median positive bias of $30 \mathrm{~m}$. This pattern is expected given that small rivers often approach the narrowest width discernable at $30 \mathrm{~m}$ spatial resolution. Classification of mixed pixels 
Table 3. Estimated discharge-measured discharge regressions.

\begin{tabular}{|c|c|c|c|c|}
\hline & Ohio & $\begin{array}{l}\text { Upper Mississippi/ } \\
\text { lower main stem }\end{array}$ & Missouri & Total \\
\hline $\begin{array}{l}\text { Regression } \\
\text { Spearman's } \rho\end{array}$ & $\begin{array}{c}y=1.00 x-0.59 \\
0.99\end{array}$ & $\begin{array}{c}y=0.98 x+1.8 \\
0.99\end{array}$ & $\begin{array}{c}y=0.95 x+2.0 \\
0.99\end{array}$ & $\begin{array}{c}y=0.98 x+0.8 \\
0.99\end{array}$ \\
\hline
\end{tabular}

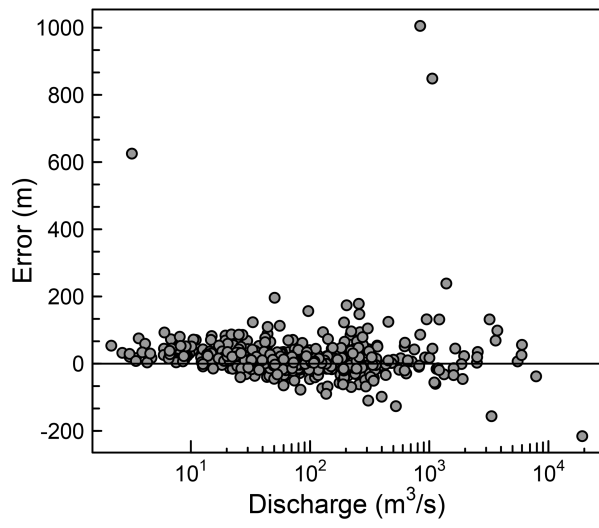

Figure 8. Width measurement error based on in situ channel measurements from 456 USGS streamflow gauging stations.

along banks imparts a theoretical minimum uncertainty of one-third the pixel resolution for each bank crossing (i.e., a minimum of $30 \mathrm{~m}$ for single-channel rivers at $30 \mathrm{~m}$ resolution; Pavelsky and Smith, 2008).

Inaccuracies associated with the measurement mechanics of RivWidth arise primarily from orthogonal angle errors. Uncertainty results from the predefined spacing of centerline segment endpoints used to define orthogonals to each centerline pixel. In highly sinuous channels where centerlines change direction rapidly, width measurements can be artificially high when orthogonals are not truly perpendicular to the channel. Basin-wide error analysis of widths calculated with endpoint spacings ranging from 7 to 21 pixels showed that inaccuracies are minimized when 11-pixel centerline segments are used, as we do here. In future studies, it may be possible to reduce this source of error by fitting a cubic spline to the channel centerline pixels as described by Legleiter and Kyriakidis (2006). Finally, although we did not attempt to quantify it here due to the large number of stations used, error associated with USGS measurements is minimized through standardized data collection methods (Buchanan and Somers, 1969; Rantz, 1982) and the careful selection of stations as described in Sect. 2.3.

\subsection{Estimation of discharge}

Using the methods described in Sect. 2.3, we estimated discharge from $0.857 \times 10^{6}$ measurements for rivers totaling $28 \times 10^{3} \mathrm{~km}$ in length and draining $2.2 \times 10^{6} \mathrm{~km}^{2}$ of the Mis-
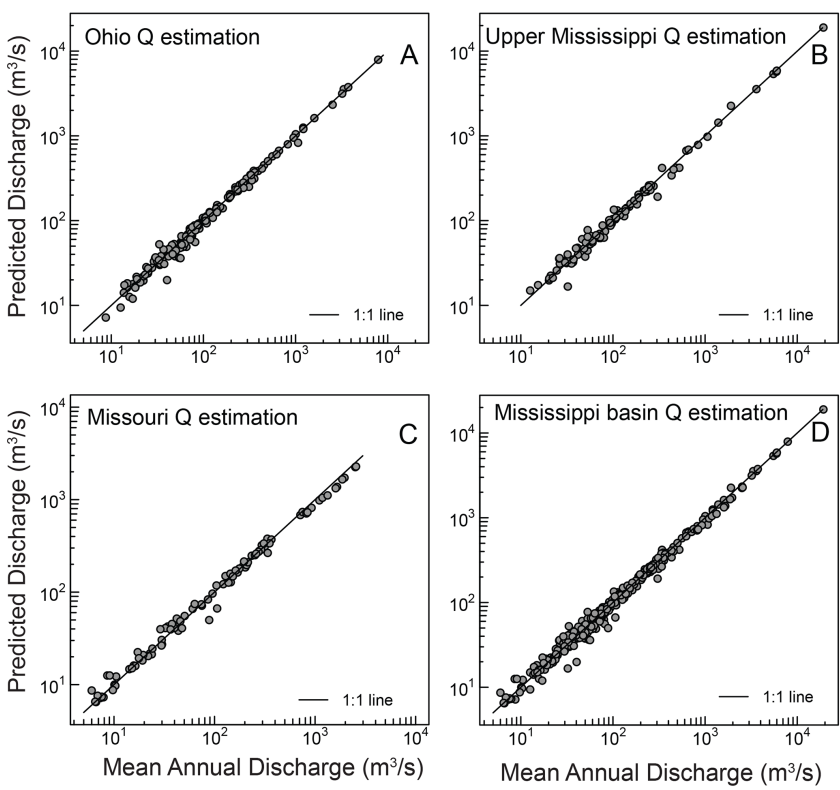

Figure 9. Estimated and USGS-measured mean discharges for 346 gauging stations in the Mississippi Basin.

sissippi Basin. To assess discharge estimate accuracy, we compared mean discharges from 346 gauging stations in the measured drainage area to the mean of the nearest five discharge estimates. Figure 9 shows the nearly $1: 1$ relationships between estimated discharge and gauge-measured discharge for major sub-basins and for the entire Mississippi. Because ordinary least-squares linear regressions are greatly influenced by high-discharge outliers, we use the Theil-Sen median estimator (Sen, 1968) to derive robust linear regressions for each sub-basin (Table 3). We use the non-parametric Spearman's $\rho$ to characterize goodness of fit, as discharges are not normally distributed. Regression slopes close to 1 and strong correlation between predicted and measured values indicate that estimates of discharge are likely accurate.

\subsection{Mississippi Basin downstream hydraulic geometry}

Using spatially continuous discharge estimates, we construct width-discharge relationships for the Mississippi Basin and, separately, three of its major sub-basins (Fig. 10a-d). Measured widths correspond to discharges ranging from 2.6 to $19200 \mathrm{~m}^{3} \mathrm{~s}^{-1}$ and drainage areas from 169 to $2940000 \mathrm{~km}^{2}$. Linear least-squares regression of log-transformed width and 

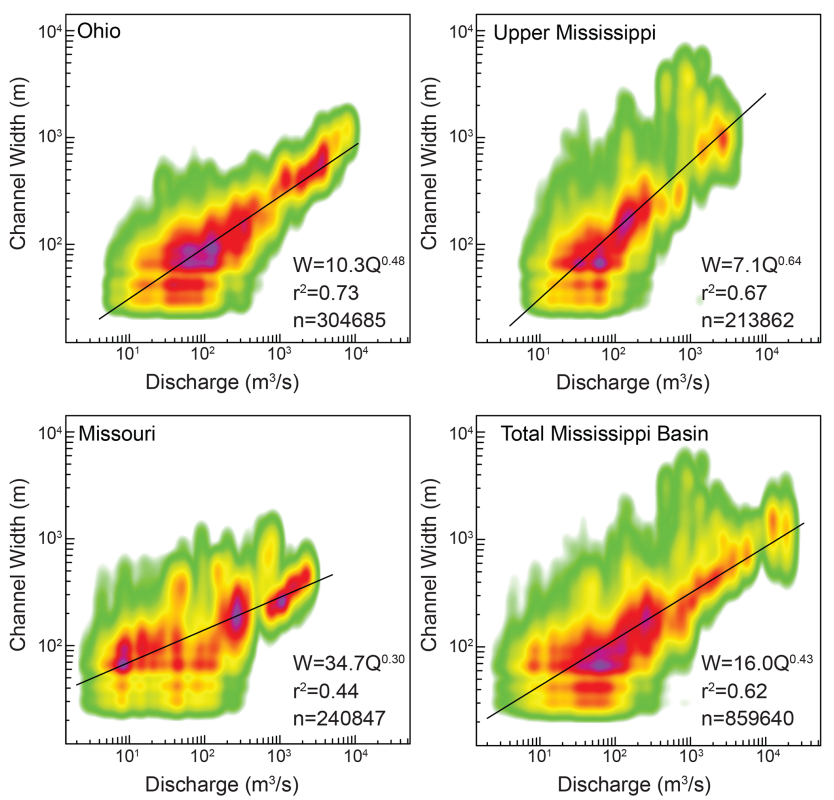

Figure 10. Density plots of width versus discharge for the Ohio, Upper Mississippi, Missouri, and entire Mississippi Basin. Linear fits represent downstream hydraulic geometry relationships analogous to Eq. (1a).

discharge shows that their relationship can be described by the power-law equation:

$w=16.0 Q^{0.43} \quad\left(r^{2}=0.62\right)$.

However, these values include 38654 width measurements corresponding to discharge values less than $10 \mathrm{~m}^{3} \mathrm{~s}^{-1}$, which are lower than would be expected for rivers greater than $30 \mathrm{~m}$ based on width-discharge relationships from Moody and Troutman (2002) and Leopold and Maddock (1953). A total of $89 \%$ (34573) of these low-discharge measurements are found in the Missouri sub-basin, where braided streams with high width / depth ratios are common. Of 38 USGS gauging stations with mean discharge $<10 \mathrm{~m}^{3} \mathrm{~s}^{-1}$, width is overestimated in all, with a mean bias of $+52 \mathrm{~m}$ (Fig. 8). As such, it is likely that basin-wide widths for discharges below $10 \mathrm{~m}^{3} \mathrm{~s}^{-1}$ result from the inability to resolve multiple channels at the $30 \mathrm{~m}$ resolution of the NLCD. If we remove these anomalous measurements, the width DHG equation becomes

$w=13.4 Q^{0.46} \quad\left(r^{2}=0.64\right)$.

These values of $a$ and $b$ fall close to the range of values calculated for world rivers by Moody and Troutman (2002). However, individual sub-basins show substantial variation from these values, with exponents ranging from 0.3 in the Missouri to 0.63 for the Upper Mississippi (Fig. 10). With the exception of the Missouri, variations in discharge account for $>50 \%$ of width variability $\left(r^{2}=0.67\right.$ and 0.73 for the Upper Mississippi and Ohio), indicating that in those sub-basins

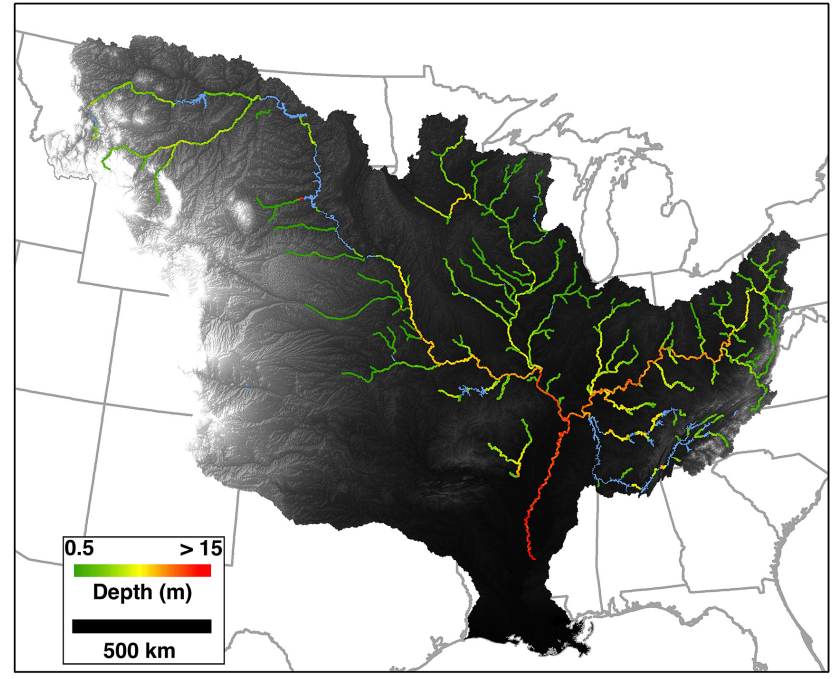

Figure 11. $8 \times 10^{5}$ mean depths in the Mississippi Basin estimated using multiple regression of $d$ against $Q$ and $w$; lakes shown in blue.

changes in discharge are the primary control on downstream variations in width. The case of the Missouri Basin will be discussed in more detail in Sect. 4.

\subsection{Estimating depth}

Using channel measurements from gauges located on streams measured by RivWidth with corresponding discharge estimates, we compared methods of estimating depth with and without width data. The first method is a simple least-squares linear regression of log-transformed depth and discharge from the gauge station data set, which results in the power-law expression

$d=0.18 Q^{0.47} \quad\left(r^{2}=0.73\right)$.

The second method is a multiple linear regression of logtransformed depth against log-transformed discharge and width, which yielded the equation

$\ln (d)=0.44-0.82 \ln (w)+0.83 \ln (Q) \quad\left(r^{2}=0.85\right)$.

Figure 11 shows depths calculated from Eq. (6) for the Ohio, Upper Mississippi, Missouri, and main stem of the Lower Mississippi using our estimated discharge and measured widths.

Basin-wide mean depth error is $41 \%$ for the two DHG estimations and $31 \%$ for the multiple regression method (Table 4). Figure 12a and b compare the percentage error of Eq. (6) to that of the two simple downstream hydraulic geometry relationships: Eq. (5) and Moody and Troutman (2002). Although mean relative error is nearly identical in the Ohio and Upper Mississippi sub-basins, the two discharge-based methods both substantially overestimate depth for seven gauging stations along the Platte River in the Missouri sub- 
Table 4. Mean absolute depth errors (\%).

\begin{tabular}{lccc}
\hline Sub-basin & $\begin{array}{c}\text { Depth } \\
\text { Only }\end{array}$ & $\begin{array}{c}\text { Depth and } \\
\text { width }\end{array}$ & $\begin{array}{c}\text { Moody- } \\
\text { Troutman }\end{array}$ \\
\hline Ohio & $29 \%$ & $29 \%$ & $31 \%$ \\
Upper & & & \\
Mississippi & $38 \%$ & $36 \%$ & $36 \%$ \\
Missouri & $58 \%$ & $30 \%$ & $58 \%$ \\
\hline Total & $41 \%$ & $31 \%$ & $41 \%$ \\
\hline
\end{tabular}

basin, leading to relative errors of $50 \%$. The disparity between approaches in the Missouri accounts for the higher error of the discharge-based equations in the basin as a whole.

\section{Discussion and conclusions}

In this study, we present one of the first high-resolution, spatially continuous width data sets covering a major river basin. The utility of remote-sensing-based measurement of channel geometry is increasingly recognized for both characterizing width-discharge relationships and applications for hydrologic modeling (Andreadis et al., 2013; Pavelsky et al., 2014; Yamazaki et al., 2014). Construction of a width frequency distribution using $1.2 \times 10^{6}$ measurements (Eq. 2) shows that Mississippi widths follow a power-law distribution $\left(n=2.1 \times 10^{9} \mathrm{~W}^{-1.9}\right)$ comparable to that found by Pavelsky et al. (2014) for the $8.5 \times 10^{5} \mathrm{~km}^{2}$ Yukon Basin $(n=$ $1.78 \times 10^{9} \mathrm{~W}^{-1.72}$ ). Similarities between these two basins - which represent highly contrasting geology, ecology, climate, and flow regimes - suggest that width distributions in other basins may follow similar patterns.

Basin-wide width-discharge relationships are characteristic of the downstream hydraulic geometry framework proposed by Leopold and Maddock (1953). However, in the global analysis of Moody and Troutman (2002), changes in discharge account for $>94 \%$ of width variation compared to $62 \%$ for the Mississippi Basin in this study. While error inherent in the RivWidth data set undoubtedly accounts for some of the higher width variability observed here, it seems unlikely that channel width corresponds as precisely to discharge as is shown in previous work. One explanation for this discrepancy is the widely spaced and non-random site selection for in situ channel measurements. To facilitate accurate discharge measurements, USGS gauging station selection criteria suggest using straight channel segments located away from tributary junctions, with only one channel and easy access (Rantz, 1982). It is not unreasonable to assume that similar site selection bias exists for most in situ channel and discharge measurement locations. In particular, the measurement bias towards single-channel rivers in previous DHG studies using gauge data may explain the higher width variability observed in this data set. Finally, previous
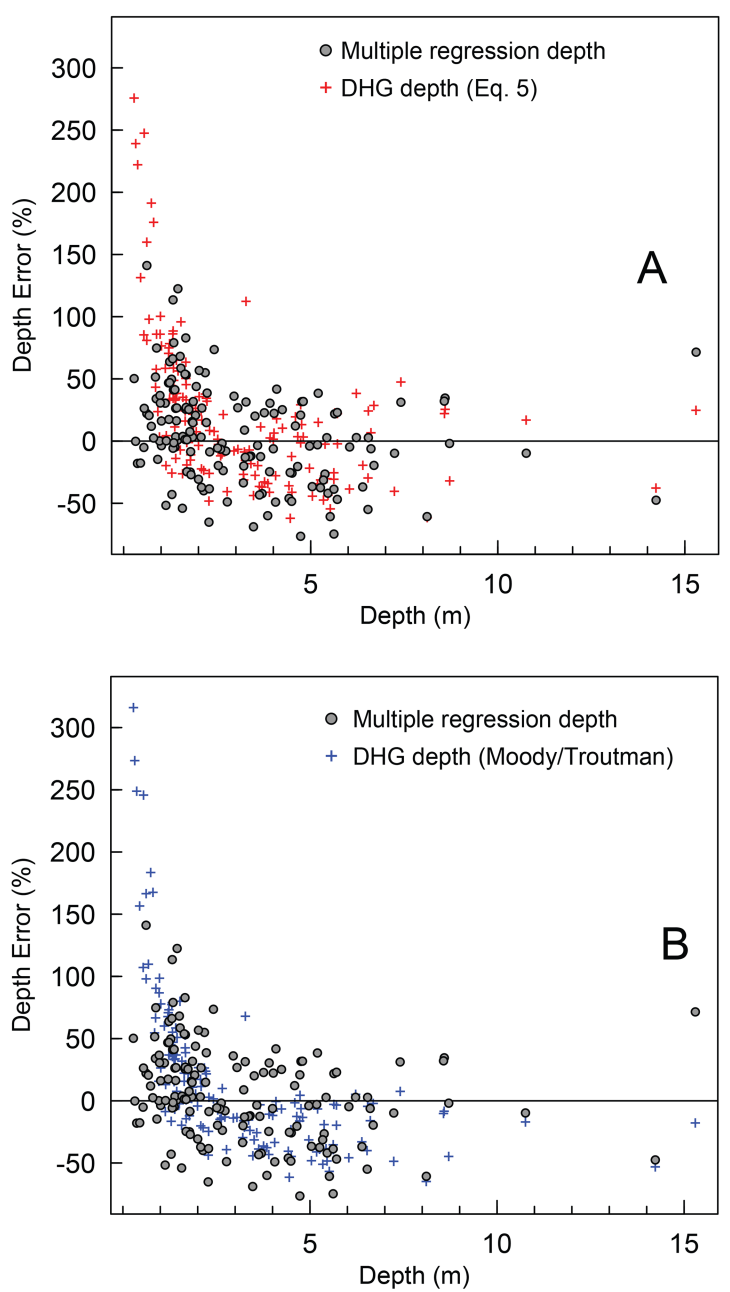

Figure 12. Relative depth error for multiple regression method (circles) and (a) DHG estimate (this study) and (b) DHG estimate (Moody and Troutman, 2002).

investigations of DHG have used data sets incorporating a much wider range of discharges (e.g., Moody and Troutman, 2002) than the rivers used in this study, which may result in higher $r^{2}$ values for those width-discharge relationships. Conversely, the fact that our data set does not include smaller streams may result in a less well-defined best-fit regression.

Individual sub-basins demonstrate different levels of adherence to traditional downstream hydraulic geometry. Missouri sub-basin channel widths increase with discharge at a much lower rate $(b=0.3)$ than has been found in previous studies (e.g., Leopold and Maddock, 1953; Moody and Troutman, 2002) with a much lower proportion of width variation explained by discharge increases $\left(r^{2}=0.44\right)$. Conversely, the Ohio sub-basin closely matches previous findings $\left(b=0.48 ; r^{2}=0.72\right)$. Several factors could explain this discrepancy. Multi-channel rivers are much more common in the Missouri sub-basin than in the Ohio; despite similar total measured lengths (Table 2) the Missouri contains 
nearly 2.5 times as many multi-channel measurements as the Ohio. While multiple channel crossings increase inherent RivWidth measurement error as explained in Sect. 3.2, braided streams are also likely to show increased width variability in response to changes in climate and flow regime (Schumm, 2005). The Missouri sub-basin also has some of the highest levels of human influence and control in North America, factors that can affect variability in channel form. In particular, dam construction has varied but pronounced effects on channel morphology (Gregory, 2006; Williams and Wolman, 1984). Williams (1978) documented highly variable channel narrowing on the Platte River as it crosses the Great Plains due to upstream flow regulation. Human impacts on stream form and flow across the central section of the Missouri drainage may lead to the high width variability and lower-than-expected increase in width with discharge observed in the Missouri sub-basin. In addition, the substantially drier climate and greater topographic relief in the upstream portions of the Missouri, relative to the Ohio or Upper Mississippi, may also influence the variations in DHG observed here by affecting the balance of water and sediment supplies in the different sub-basins.

Human influence also likely plays a role in the high $b$ value (0.64) observed in the Upper Mississippi sub-basin. In larger rivers - particularly along the main stem of the Mississippi lock and dam control structures artificially widen the channel or connect it to secondary channels in its floodplain. Because of difficulties in differentiating the main stem of the Mississippi from ancillary channels and inundated floodplains that connect to the main channels in the NLCD, these features are included in the width-discharge data set. While the high $b$ value may not represent the natural width changes, we believe it accurately describes present-day inundation extent along the Upper Mississippi more effectively than would a lower width exponent.

In sub-basins with well-developed width-discharge relationships, traditional depth-discharge DHG predicts depth well without inclusion of additional information on river width. In the Ohio and Upper Mississippi sub-basins, depth estimates based on the two $d-Q$ relationships show similar accuracy to that of the multiple regression estimation that incorporates width (Eq. 6). In the Missouri sub-basin, however, both traditional DHG methods substantially overestimate depth for wide, shallow rivers compared to the multiple regression analysis. Although basin-wide absolute error is not significantly reduced, consistent overestimation of depth for wide, shallow rivers like the Platte suggests that in applications where depths are based on downstream hydraulic geometry (e.g., Alexander, 2000), factoring width into depth estimations substantially reduces uncertainty. This improvement results from the underlying assumption of continuity in the relationship between depth, discharge, width, and velocity; measuring width while assuming locally constant flow eliminates one degree of freedom from the depth equation.
Several potential sources of error must be addressed when studying channel form using remotely sensed data. The largest sources of uncertainty in our Mississippi data set are inherent to the input imagery. Because higher pixel resolution decreases classification error, increases total channel length, and decreases the size of the smallest rivers measured, selecting appropriate input data is critical. Figure 7 indicates that all rivers greater than 3 times the pixel resolution and substantial numbers of smaller rivers are measured. While our results suggest that the NLCD represents an approximation of river extent close to mean discharge, there are clear instances where channels are wider than expected due to connectivity with the surrounding floodplain, misclassification of channel boundary pixels, or potential use of images taken during times of higher-than-mean flows. To reduce the error associated with the input water mask, future investigations should use a consistent and effective river classification scheme on images taken during periods of the desired flow state. Finally, RivWidth must be configured properly, as the segment length used to calculate the orthogonal direction can create non-perpendicular cross sections when poorly chosen. Other methods of calculating orthogonals to the river centerline, especially implementation of algorithms described by Legleiter and Kyriakidis (2006), may help to minimize this source of error in future studies.

Provided these sources of error are addressed, RivWidth offers the capability to measure river width at a high resolution over large basins with small and predictable error. Despite the importance of river form and flow, in situ river monitoring capabilities have declined over the last several decades (Vörösmarty et al., 2001), highlighting the importance of remote sensing techniques that can produce highresolution, spatially continuous observations of river channels over large areas (Alsdorf et al., 2007). Although significant challenges remain in using remotely sensed channel observations to produce discharge measurements, non-realtime estimations of river flow relying on width measurement have been made (LeFavour and Alsdorf, 2005; Smith and Pavelsky, 2008). In addition, multivariate equations for prediction of streamflow (e.g., Bjerklie et al., 2003) often combine river width measurements with information on slope and other river form data. As the most widely observable of the three primary dimensions of river discharge, understanding variations in width is a critical first step in characterizing discharge from remotely sensed data. Because RivWidth produces maps of river centerline, it may be useful in characterizing the planform shape of rivers (e.g., via indices of sinuosity and braiding), which would help to reveal downstream patterns in river form. Additionally, intersection of river centerlines with a high-resolution DEM would allow estimation of mean slope, another key variable in understanding river form (Bjerklie, 2007).

In addition to its importance in the measurement of discharge, remote sensing of river width contributes to the accuracy of hydrologic and hydraulic modeling. While width 
parameters are often characterized through empirically derived discharge relationships (e.g., Yamazaki et al., 2011; Andreadis et al., 2013), the utility of widths from satellite imagery in improving hydraulic modeling of river and floodplain dynamics is increasingly recognized (Neal et al., 2012; Schumann et al., 2009). Given growing interest in river modeling at continental and global scales and the importance of rivers in natural and human systems, this paper and other recent studies (e.g., Yamazaki et al., 2014) demonstrate how data from future satellite missions such as the Surface Water and Ocean Topography (SWOT) mission (jointly under development by the United States and France) can measure the spatial and temporal variability in Earth's surface water resources (Fu et al., 2012). These products, combined with ongoing work to produce Landsat-derived width data sets globally, will allow for more accurate characterization of spatial variability in channel form than is currently afforded by empirically derived estimation methods

Acknowledgements. This study was funded by NASA New Investigator Grant no. NNX12AQ77G, managed by Ming-Ying Wei. We thank Benjamin Mirus for his thoughtful comments on a draft of the manuscript. We also thank Carl Legleiter, Mark Fonstad, and one anonymous reviewer for their useful suggestions.

Edited by: P. Passalacqua

\section{References}

Alexander, R. B., Smith, R. A., and Schwarz, G. E.: Effect of stream channel size on the delivery of nitrogen to the Gulf of Mexico, Nature, 403, 758-761, 2000.

Allen, G. H., Barnes, J. B., Pavelsky, T. M., and Kirby, E.: Lithologic and tectonic controls on bedrock channel form at the northwest Himalayan front, J. Geophys. Res. Earth Surf., 118, 18061825, doi:10.1002/jgrf.20113, 2013.

Alsdorf, D. E., Rodríguez, E., and Lettenmaier, D. P.: Measuring surface water from space, Rev. Geophys., 45, RG2002, doi:10.1029/2006RG000197, 2007.

Amos, C. B. and Burbank, D. W.: Channel width response to differential uplift, J. Geophys. Res., 112, F02010, doi:10.1029/2006JF000672, 2007.

Andreadis, K. M., Schumann, G., and Pavelsky, T. M.: A simple global river bankfull width and depth database, Water Resour. Res., 49, 7164-7168, doi:10.1002/wrcr.20440, 2013.

Apel, H., Aronica, G. T., Kreibich, H., and Thieken, A. H.: Flood risk analyses - how detailed do we need to be?, Natural Hazards, 49, 79-98, doi:10.1007/s11069-008-9277-8, 2009.

Ayres, J. M. and Clutton-Brock, T. H.: River boundaries and species range size in Amazonian primates, The American Naturalist, 140, 531-537, 1992.

Bellasis, E. S.: River and canal engineering: the characteristics of open flowing streams, and the principles and methods to be followed in dealing with them, E. \& F. N. Spon, Limited, London, 1913.
Bjerklie, D. M.: Estimating the bankfull velocity and discharge for rivers using remotely sensed river morphology information, J Hydrol., 341, 144-155, 2007.

Bjerklie, D. M., Dingman, S. L., Vorosmarty, C. J., Bolster, C. H., and Congalton, R. G.: Evalulating the potential for measuring river discharge from space, J. Hydrol., 278, 17-38, 2003.

Bowen, M. W. and Juracek, K. E.: Assessment of the Geomorphic Effects of Large Floods Using Streamgage Data: the 1951 Floods in Eastern Kansas, USA, Phys. Geogr., 32, 52-77, 2011

Buchanan, T. J. and Somers, W. P.: Discharge measurements at gaging stations, U.S. Geol. Surv. Tech. Water Resour. Invest, Book 3, Chap. A8, United States Government Printing Office, Washington 1969.

Butman, D. and Raymond, P. A.: Significant efflux of carbon dioxide from streams and rivers in the United States, Nature Geoscience, 4, 839-842, doi:10.1038/NGEO1294, 2011.

Carleton, J. N., and Mohamoud, Y. M.: Effect of Flow Depth and Velocity on Nitrate Loss Rates in Natural Channels1, J. Am. Water. Resour. As., 49, 205-216, doi:10.1111/jawr.12007, 2013.

Chaplin, J. J.: Development of regional curves relating to bankfullchannel geometry and discharge to drainage area for streams in Pennsylvania and selected areas of Maryland, U.S. Geol. Surv. Scientific Investigations Report 2005-5147, 40 pp., 2005.

Fonstad, M. A. and Marcus, W. A.: Remote sensing of stream depths with hydraulically assisted bathymetry (HAB) models, Geomorphology, 72, 320-339, doi:10.1016/j.geomorph.2005.06.005, 2005.

Fu, L. L., Alsdorf, D., Morrow, R., Rodriguez, E., and Mognard, N. (Eds.): SWOT: The Surface Water and Ocean Topography Mission, in: Wide-Swath Altimetric Measurement of Water Elevation on Earth, JPL-Publication 12-05, Jet Propul. Lab., Pasadena, Calif., 228 pp., 2012.

Galster, J. C., Pazzaglia, F. J., Hargreaves, B. R., Morris, D. P., Peters, S. C., and Weisman, R. N.: Effects of urbanization on watershed hydrology: The scaling of discharge with drainage area, Geology, 34, 713-716, doi:10.1130/G22633.1, 2006.

Garrett, W. P.: River meanders and channel size, J. Hydrol., 88, $147-$ $164,1986$.

Gregory, K. J.: The human role in changing river channels, Geomorphology, 79, 172-191, doi:10.1016/j.geomorph.2006.06.018, 2006.

Griffiths, G. A.: Hydraulic geometry relationships of some New Zealand gravel bed rivers. Journal of Hydrology (NZ), 19, 106$118,1980$.

Harbor, D. J.: Dynamic equilibrium between an active uplift and the Sevier River, Utah, J. Geol., 106, 181-194, 1998.

Hayes, F. E. and Sewlal, J. A. N.: The Amazon River as a dispersal barrier to passerine birds: effects of river width, habitat and taxonomy, J. Biogeography, 31, 1809-1818, 2004.

Hobley, D. E., Sinclair, H. D., and Mudd, S. M.: Reconstruction of a major storm event from its geomorphic signature: The Ladakh floods, 6 August 2010, Geology, 40, 483-486, doi:10.1130/G32935.1, 2012.

Homer, C., Huang, C., Yang, L., Wylie, B., and Coan, M.: Development of a 2001 national land cover database for the United States, Photogramm. Eng. Remote Sens., 70, 829-840, 2004.

Humphreys, C. A. and Abbot, L. H.: Report upon the physics and hydraulics of the Mississippi River, US Government Printing Office, Washington, DC, 1867. 
Ibbitt, R. P.: Evaluation of optimal channel network and river basin heterogeneity concepts using measured flow and channel properties, J. Hydrology, 196, 119-138, 1997.

Jowett, I. G.: Hydraulic geometry of New Zealand rivers and its use as a preliminary method of habitat assessment, Regul. Rivers, 14, 451-466, 1998.

Juracek, K. E. and Fitzpatrick, F. A.: Geomorphic applications of stream-gage information, River Research and Applications, 25, 329-347, 2009.

Klein, M.: Drainage area and the variation of channel geometry downstream, Earth Surf. Process. Landforms, 6, 589-593, 1981.

Knighton, A. D.: Variation in width-discharge relation and some implications for hydraulic geometry, Geol. Soc. Am. Bull., 85, 1069-1076, 1974.

Lee, J. S. and Julien, P. Y.: Downstream hydraulic geometry of alluvial channels, J. Hyd. Eng, 132, 1347-1352, 2006.

LeFavour, G., and Alsdorf, D.: Water slope and discharge in the Amazon River estimated using the shuttle radar topography mission digital elevation model, Geophys. Res. Lett., 32, L17404, doi:10.1029/2005GL023836, 2005.

Legleiter, C. J.: Mapping river depth from publicly available aerial images, River Res. Appl., 29, 760-780, doi:10.1002/rra.2560, 2012.

Legleiter, C. J. and Kyriakidis, P. C.: Forward and inverse transformations between Cartesian and channel-fitted coordinate systems for meandering rivers, Math. Geol., 38, 9270958, doi:10.1007/s11004-006-9056-6, 2006.

Lehner, B., Verdin, K., and Jarvis, A.: New Global Hydrography Derived From Spaceborne Elevation Data, Eos Trans. AGU, 89, 93-94, doi:10.1029/2008eo100001, 2008.

Leopold, L. B. and Maddock, T.: The hydraulic geometry of stream channels and some physiographic implications, U.S. Geol. Surv. Prof. Paper, 252, United States Government Printing Office, Washington, 1953.

Leopold, L.B. and Miller, J. P.: Ephemeral streams - hydraulic factors and their relation to the drainage net, U.S. Geol. Surv. Prof. Paper 282-a, United States Government Printing Office, Washington, 1956.

McCartney, B.: Inland Waterway Navigation Project Design, J. Waterway, Port, Coastal, Ocean Eng., 112, 645-657, 1986.

Mersel, M. K., Smith, L. C., Andreadis, K. M., and Durand, M. T.: Estimation of river depth from remotely sensed hydraulic relationships, Water Resour. Res., 49, 3165-3179, doi:10.1002/wrcr.20176, 2013.

Molnar, P. and Ramirez, J. A.: On downstream hydraulic geometry and optimal energy expenditure: case study of the Ashley and Taieri Rivers. J. Hydrology, 259, 105-115, 2002.

Montgomery, D. R.: Observations on the role of lithology in strath terrace formation and bedrock channel width, Am. J. Science, 304, 454-476, 2004.

Montgomery, D. R. and Gran, K. B.: Downstream variations in the width of bedrock channels, Water Resour. Res., 37, 1841-1846, doi:10.1029/2000WR900393, 2001.

Moody, J. A. and Troutman, B. M.: Characterization of the spatial variability of channel morphology, Earth Surf. Proc. Land., 27, 1251-1266, doi:10.1002/esp.403, 2002.

Neal, J., Schumann, G., and Bates, P.: A subgrid channel model for simulating river hydraulics and floodplain inundation over large and data sparse areas, Water Resour. Res., 48, W11506, doi:10.1029/2012WR012514, 2012.

Newson, M. D. and Newson, C. L.: Geomorphology, ecology and river channel habitat: mesoscale approaches to basin-scale challenges, Prog. Phys. Geog., 24, 195-217, 2000.

Osterkamp, W. R. and Hedman, E. R.: Perennial streamflow characteristics related to channel geometry and sediment in the Missouri River Basin, USGS Professional Paper, 1242 pp., 1982.

Paiva, R. C. D., Buarque, D. C., Collischonn, W., Bonnet, M.-P., Frappart, F., Calmant, S., and Mendes, C. A. B.: Large- scale hydrologic and hydrodynamic modeling of the Amazon River basin, Water Resour. Res., 49, 1226-1243, doi:10.1002/wrcr.20067, 2013.

Park, C. C.: World-wide variations in hydraulic geometry exponents of stream channels: an analysis and some observations, J. Hydrology, 33, 133-146, 1977.

Pavelsky, T. M. and Smith, L. C.: RivWidth: A software tool for the calculation of river widths from remotely sensed imagery, IEEE Geosci. Remote S., 5, 70-73, 2008.

Pavelsky, T. M. and Smith, L. C.: Remote sensing of suspended sediment concentration, flow velocity, and lake recharge in the Peace-Athabasca Delta, Canada, Water Resour. Res, 45, W11417, doi:10.1029/2008WR007424, 2009.

Pavelsky, T. M., Allen, G. H., and Miller, Z. F.: Remote Sensing of river widths in the Yukon River Basin, in: Remote Sensing of the Terrestrial Water Cycle, edited by: Lakshmi, V., Geophysical Monograph 206, American Geophysical Union, Washington, 131-141, 2014.

Pazzaglia, F. J., Gardner, T. W., and Merritts, D. J.: Bedrock fluvial incision and longitudinal profile development over geologic time scales determined by fluvial terraces, in: Rivers over rock: Fluvial processes in bedrock channels, edited by: Tinkler, K. J. and Wohl, E. E., American Geophysical Union Geophysical Monograph, 107, 207-236, American Geophysical Union, Washington, 1998.

Peterson, B. J., Wollheim, W. M, Mulholland, P. J., Webster, J. R., Meyer, J. L., Tank, J. L., Marti, E., Bowden, W. B., Valett, H.M., Hershey, A. E., McDowell, W. H., Dodds, W. K., Hamilton, S. K., Gregory, S., and Morrall, D. D.: Control of nitrogen export from watersheds by headwater streams, Science, 292, 8690, doi:10.1126/science.1056874, 2001.

Pietsch, T. J. and Nanson, G. C.: Bankfull hydraulic geometry; the role of in-channel vegetation and downstream declining discharges in the anabranching and distributary channels of the Gwydir distributive fluvial system, southeastern Australia, Geomorphology, 129, 152-165, doi:10.1016/j.geomorph.2011.01.021, 2011.

Prevost, E., Parent, E., Crozier, W., Davidson, I., Dumas, J., Gudbergsson, G., Hindar, K., McGinnity, P., MacLean, J., and Saettemi, L. M.: Setting biological reference points for Atlantic salmon stocks: transfer of information from data-rich to sparsedata situations by Bayesian hierarchical modeling, ICES J. Mar. Sci, 60, 1177-1193, doi:10.1016/j.icesjms.2003.08.001, 2003.

Rango, A. and Salomonson, V. V.: Regional flood mapping from space, Water Resour. Res., 10, 473-484, doi:10.1029/WR010i003p00473, 1974.

Rantz, S. E.: Measurement and computation of streamflow; Volume 1 , measurement of stage and discharge, US Geological Survey 
Water-Supply Paper, 2175 pp., United States Government Printing Office, Washington, 1982.

Raymond, P. A., Hartmann, J., Lauerwald, R., Sobek, S., McDonald, C., Hoover, M., Butman, D., Striegl, R., Mayorga, E., Humborg, C., Kortelainen, P., Durr, H., Meybeck, M., Ciais, P., and Guth, P.: Global carbon dioxide emissions from inland waters, Nature, 503, 355-359, 2013.

Sabo, J. L. and Hagen, E. M.: A network theory for resource exchange between rivers and their watersheds, Water Resour. Res, 48, W0515, doi:10.1029/2011WR010703, 2012.

Schumann, G., Bates, P. D., Horritt, M. S., Matgen, P., and Pappenberger, F.: Progress in integration of remote sensing-derived flood extent and stage data and hydraulic models, Rev. Geophys., 47, RG4001, doi:10.1029/2008RG000274, 2009.

Schumm, S. A.: River variability and complexity, Cambridge University Press, Cambridge, UK, 2005.

Sen, P. K.: Estimates of the regression coefficient based on Kendall's tau, J Am. Stat. Assoc., 63, 1379-1389, 1968.

Shepherd, R. G. and Ellis, B. N: Leonardo da Vinci's Tree and the Law of Channel Widths - Combining Quantitative Geomorphology and Art in Education, J. Geoscience Education, 45, 425-427, 1997.

Smith, L. C. and Pavelsky, T. M.: Estimation of river discharge, propagation speed and hydraulic geometry from space: Lena River, Siberia, Water Resour. Res., 44, W03427, doi:10.1029/2007WR006133, 2008.

Smith, L. C., Isacks, B. L., Bloom, A. L., and Murray, A. B.: Estimation of discharge from three braided rivers using synthetic aperture radar satellite imagery: Potential application to ungaged basins, Water Resour. Res., 32, 2021-2034, doi:10.1029/96WR00752, 1996.

Stall, J. B. and Fok Y.: Hydraulic geometry of Illinois streams, University of Illinois Water Resources Center Research Report no. 15, 52 pp., 1968.

Stover, S. C. and Montgomery, D. R.: Channel change and flooding, Skokomish River, Washington, J. Hydrology, 243, 272-286, 2001.

Tague, C. and Grant, G. E.: A geological framework for interpreting the low-flow regimes of Cascade streams, Willamette River Basin, Oregon, Water Resour. Res., 40, W04303, doi:10.1029/2003WR002629, 2004.
Troitsky, M. S.: Planning and design of bridges, John Wiley, New York, NY, 1994.

Tucker, G. E. and Bras, R. L.: Hillslope processes, drainage density, and landscape morphology, Water Resour. Res., 34, 2751-2764, doi:10.1029/98WR01474, 1998.

Vörösmarty, C., Askew, A., Berry, R., Birkett, C., Döll, P., Grabs, W., Hall, A., Jenne, R., Kitaev, L., Landwehr, J., Keeler, M., Leavesley, G., Schaake, J., Strzepek, K., Sundarvel, S., Takeuchi, K., and Webster, F.: Global water data: A newly endangered species, EOS Trans. AGU 82, 54-58, 2001.

Watson, J. P.: A visual interpretation of a Landsat mosaic of the Okavango Delta and surrounding area. Remote Sens. Environ., 35, 1-9, 1991.

Whipple, K. X.: Bedrock rivers and the geomorphology of active orogens. Annu. Rev. Earth Planet. Sci., 32, 151-185, doi:10.1146/annurev.earth.32.101802.120356, 2004.

Wickham, J. D., Stehman, S. V., Fry, J. A., Smith, J. H., and Homer, C. G.: Thematic accuracy of the NLCD 2001 land cover for the conterminous United States, Remote Sens. Env., 114, 12861296., doi:10.1016/j.rse.2010.01.018, 2010.

Williams, G. P.: The case of the shrinking channels - the North Platte and Platte Rivers in Nebraska, US Geological Survey Circular 781, United States Government Printing Office, Washington, 1978.

Williams, G. P. and Wolman, M. G.: Downstream effects of dams on alluvial rivers, U.S. Geol. Surv. Prof. Paper, 1286, United States Government Printing Office, Washington, 83 pp., 1984.

Wollheim, W. M., Vörösmarty, C. J., Peterson, B. J., Seitzinger, S. P., and Hopkinson, C. S.: Relationship between river size and nutrient removal, Geophys. Res. Lett., 33, L06410, doi:10.1029/2006GL025845, 2006.

Wolman, M. G.: The natural channel of Brandywine Creek, Pennsylvania, U.S. Geol. Surv. Prof. Paper 271, 56 pp., United States Government Printing Office, Washington, 1955.

Yamazaki, D., Kanae, S., Kim, H., and Oki, T.: A physically based description of floodplain inundation dynamics in a global river routing model, Water Resour. Res., 47, W04501, doi:10.1029/2010WR009726, 2011.

Yamazaki, D., O’Loughlin, F., Trigg, M. A., Miller, Z. F., Pavelsky, T. M., and Bates, P. D.: Development of the Global Width Database for Large Rivers, Water Resour. Res., 50, 3467-3480, 2014. 